\title{
SARS-CoV-2 variant of concern B.1.1.7: diagnostic accuracy of three antigen-detecting rapid tests
}

Andreas K. Lindner ${ }^{1}$, Lisa J. Krüger ${ }^{2}$, Olga Nikolai ${ }^{1}$, Julian A.F. Klein ${ }^{2}$, Heike Rössig ${ }^{3}$, Paul Schnitzler ${ }^{4}$, Victor M. Corman ${ }^{5,6}$, Terry C. Jones ${ }^{5,6,7}$, Frank Tobian ${ }^{2}$, Mary Gaeddert ${ }^{2}$, Susen Burock $^{8}$, Jilian A. Sacks ${ }^{9}$, Joachim Seybold ${ }^{3}$, Frank P. Mockenhaupt ${ }^{1}$ and Claudia M. Denkinger ${ }^{2,10}$

${ }^{1}$ Charité - Universitätsmedizin Berlin, corporate member of Freie Universität Berlin and HumboldtUniversität zu Berlin, Institute of Tropical Medicine and International Health, Berlin, Germany

${ }^{2}$ Division of Clinical Tropical Medicine, Center of Infectious Diseases, Heidelberg University Hospital, Germany

${ }^{3}$ Charité - Universitätsmedizin Berlin, corporate member of Freie Universität Berlin and HumboldtUniversität zu Berlin, Medical Directorate, Berlin, Germany

${ }^{4}$ Department of Virology, Centre of Infectious Diseases, Heidelberg University Hospital, Germany

${ }^{5}$ Charité - Universitätsmedizin Berlin, corporate member of Freie Universität Berlin and HumboldtUniversität zu Berlin, Institute of Virology, Berlin, Germany

${ }^{6}$ German Centre for Infection Research (DZIF), partner site Charité, 10117 Berlin, Germany

${ }^{7}$ Centre for Pathogen Evolution, Department of Zoology, University of Cambridge, Downing St., Cambridge, CB2 3EJ, U.K.

${ }^{8}$ Charité - Universitätsmedizin Berlin, corporate member of Freie Universität Berlin and HumboldtUniversität zu Berlin, Charité Comprehensive Cancer Center, Berlin, Germany

${ }^{9}$ Foundation for Innovative New Diagnostics, Geneva, Switzerland

${ }^{10}$ German Centre for Infection Research (DZIF), partner site Heidelberg, 69120 Heidelberg, Germany

Correspondence: Claudia M. Denkinger, Division of Clinical Tropical Medicine, Heidelberg University Hospital, Im Neuenheimer Feld 672, 69120 Heidelberg, Germany. E-mail: claudia.denkinger@uniheidelberg.de 
medRxiv preprint doi: https://doi.org/10.1101/2021.06.15.21258502; this version posted June 15, 2021. The copyright holder for this preprint (which was not certified by peer review) is the author/funder, who has granted medRxiv a license to display the preprint in perpetuity.

It is made available under a CC-BY-NC-ND 4.0 International license .

\section{Abstract}

Virus mutations have the potential to impact the accuracy of diagnostic tests. The SARS-CoV2 B.1.1.7 lineage is defined by a large number of mutations in the spike gene and four in the nucleocapsid (N) gene. Most commercially available SARS-CoV-2 antigen-detecting rapid tests (Ag-RDTs) target the viral N-protein, encoded by the $\mathrm{N}$-gene.

We conducted a manufacturer-independent, prospective diagnostic accuracy study of three SARS-CoV-2 Ag-RDTs that are currently under review by the WHO Emergency Use Listing Procedure (Espline - Fujirebio Inc.; Sure Status - Premier Medical Corporation Private Limited; Mologic - Mologic Ltd.) and report here on an additional sub-analysis regarding the B.1.1.7 lineage. During the study, in Berlin and Heidelberg, Germany, from 20 January to 15 April 2021, B.1.1.7 rapidly became the dominant SARS-CoV-2 lineage at the testing sites and was detected in 220 (62\%) of SARS-CoV-2 RT-PCR positive patients. All three Ag-RDTs yielded comparable sensitivities irrespective of an infection with the B.1.1.7 lineage or not.

There is only limited data on how $\mathrm{N}$-gene mutations in variants of concern may impact AgRDTs. Currently, no major changes to test performance are anticipated. However, test developers and health authorities should assess and monitor the impact of emerging variants on the accuracy of Ag-RDTs. 
medRxiv preprint doi: https://doi.org/10.1101/2021.06.15.21258502; this version posted June 15, 2021. The copyright holder for this preprint (which was not certified by peer review) is the author/funder, who has granted medRxiv a license to display the preprint in perpetuity.

It is made available under a CC-BY-NC-ND 4.0 International license .

\section{Manuscript}

The SARS-CoV-2 B.1.1.7 lineage (recently labelled as Alpha by WHO), also known as variant of concern (VOC) 202012/01, rapidly emerged after its first identification in the United Kingdom in late 2020 (1). As of 1 June 2021, B.1.1.7 has been verified in 160 countries and become the dominant variant in several European countries, including Germany, and in North America (2-4). B.1.1.7 is defined by a large number of mutations in the spike (S) gene and four in the nucleocapsid (N) gene (N-protein: D3L, R203K, G204R, and S235F) (5). Virus mutations have the potential to impact the accuracy of diagnostic tests. Most commercially available SARS-CoV-2 antigen-detecting rapid tests (Ag-RDTs) target the C-terminus of the viral N-protein, encoded by the $\mathrm{N}$-gene $(6,7)$. The $\mathrm{N}$-gene mutations of B.1.1.7 are located at the N-terminus (7). In an evaluation by Public Health England, the B.1.1.7 variant did not affect the performance of six commercially available Ag-RDTs, despite a limited number of amino acid changes from the original viral sequence in the target antigen $(5,8)$.

We conducted a manufacturer-independent, prospective diagnostic accuracy study of three SARS-CoV-2 Ag-RDTs at an ambulatory testing facility in Berlin and Heidelberg, Germany, from 20 January to 15 April 2021. All three Ag-RDTs evaluated are currently under review by the WHO Emergency Use Listing Procedure: 1) Espline SARS-CoV-2 (Fujirebio Inc.); 2) Sure Status COVID-19 Antigen Card Test (Premier Medical Corporation Private Limited), both using nasopharyngeal sampling; and 3) Mologic COVID-19 Rapid Test (Mologic Ltd.), using anterior nasal sampling (9). Reference standard was RT-PCR using naso-/oropharyngeal sampling. Study procedures were previously described (10). The study was conducted in collaboration with the Foundation of Innovative New Diagnostics (FIND), a WHO Collaborating Centre. Here we report on an additional sub-analysis regarding the B.1.1.7 lineage.

Of 1692 adults enrolled in the study, 354 (21\%) tested positive by RT-PCR. Positive samples were typed for the N501Y and del69-70 polymorphisms by melting curve analysis. The presence of both polymorphisms was considered indicative of a B.1.1.7 lineage infection, an inference whose accuracy was confirmed by full-genome sequencing of all Heidelberg samples. During the study, B.1.1.7 became the dominant SARS-CoV-2 lineage within only five weeks (11). Among the positive patients, 220 (62\%) were infected with B.1.1.7, 3 (1\%) with VOC B.1.351 and 109 (31\%) with wildtype virus or mutations that are currently considered 
medRxiv preprint doi: https://doi.org/10.1101/2021.06.15.21258502; this version posted June 15, 2021. The copyright holder for this preprint (which was not certified by peer review) is the author/funder, who has granted medRxiv a license to display the preprint in perpetuity.

It is made available under a CC-BY-NC-ND 4.0 International license .

not of concern. All three Ag-RDTs yielded comparable sensitivities irrespective of an infection with the B.1.1.7 lineage or not (Table 1). In 22 (6\%) patients, typing was not done or not possible due to the limit of detection of genotyping for samples with low viral load (excluded from analysis and leading to a slight overestimation of sensitivity).

There is only limited data on how N-gene mutations in VOCs may impact Ag-RDTs and this clinical evaluation complements analytical evaluations $(5,8,12,13)$. Currently, no major changes to test performance are anticipated (6). However, test developers and health authorities should assess and monitor the impact of emerging variants on Ag-RDTs during development and post-authorization (14).

TABLE 1 Results of three antigen rapid tests with sensitivity, median duration of symptoms, and median viral load for 329 RT-PCR positive patients with viral typing. Results from patients infected with B.1.1.7 are shown separately from others (i.e., infected with wildtype virus or other mutations). Sensitivities are slightly overestimated due to the limit of detection of genotyping for samples with low viral load.

\begin{tabular}{|c|c|c|c|c|c|}
\hline $\begin{array}{c}\text { SARS-CoV-2 } \\
\text { Variant }\end{array}$ & $\begin{array}{l}\text { Ag-Test } \\
\text { positive }\end{array}$ & $\begin{array}{l}\text { Ag-Test } \\
\text { negative }\end{array}$ & $\begin{array}{l}\text { Sensitivity } \\
(95 \% \mathrm{Cl})\end{array}$ & $\begin{array}{c}\text { Days of symptoms } \\
\text { Median [IQR] }\end{array}$ & $\begin{array}{c}\text { Viral load }^{1} \\
\text { Median [IQR] }\end{array}$ \\
\hline \multicolumn{6}{|c|}{ Espline Fujirebio $^{3}$} \\
\hline B.1.1.7 & 16 & 1 & $94.1 \%(73.0-99.7)$ & $2[1-3]$ & $8.00[7.36-8.58]$ \\
\hline others ${ }^{2}$ & 69 & 12 & $85.2 \%(75.9-91.3)$ & $3[1-4]$ & $8.01[6.52-8.82]$ \\
\hline \multicolumn{6}{|c|}{ Sure Status $^{4}$} \\
\hline B.1.1.7 & 71 & 5 & $93.4 \%(85.5-97.2)$ & $3[1-5]$ & $8.22[7.02-9.04]$ \\
\hline others $^{2}$ & 17 & 2 & $89.5 \%$ (68.6-97.1) & $2[1-4]$ & $8.11[7.66-8.83]$ \\
\hline \multicolumn{6}{|c|}{ Mologic ${ }^{5,6}$} \\
\hline B.1.1.7 & 154 & 15 & $91.1 \%(85.9-94.5)$ & $2[1-4]$ & $8.45[7.51-9.17]$ \\
\hline others ${ }^{2}$ & 17 & 1 & $94.4 \%(74.2-99.7)$ & $3[2-4]$ & 7.52 [6.88-8.40] \\
\hline
\end{tabular}

${ }^{1} \log _{10}$ SARS-CoV2 RNA copies/ml; ${ }^{2}$ including 1 patient with VOC B.1.351 with positive Ag-Test (one with each test); ${ }^{3}$ Espline SARS-CoV-2 (Fujirebio Inc.); ${ }^{4}$ Sure Status COVID-19 Antigen Card Test (Premier Medical Corporation Private Limited); ${ }^{5}$ Mologic COVID-19 Rapid Test (Mologic Ltd.); ${ }^{3-5}$ In part, two Ag-Tests were performed on an individual patient, with first an anterior nasal swab (Mologic) and subsequently the nasopharyngeal swab (Sure Status or Espline Fujirebio); ${ }^{6}$ exclusion of 3 RT-PCR positive patients with in valid Ag-RDT. 
medRxiv preprint doi: https://doi.org/10.1101/2021.06.15.21258502; this version posted June 15, 2021. The copyright holder for this preprint (which was not certified by peer review) is the author/funder, who has granted medRxiv a license to display the preprint in perpetuity.

It is made available under a CC-BY-NC-ND 4.0 International license .

Author contributions: AKL: conceptualization, methodology, writing - original draft. LK: investigation, formal analysis. ON: methodology, investigation, formal analysis. JAFK: investigation, formal analysis. HR: project administration. PS: investigation, formal analysis. VMC: investigation, formal analysis. TCJ: investigation, formal analysis. FT: formal analysis. MG: formal analysis. SB: project administration. JAS: supervision. JS: supervision, project administration. FPM: conceptualization, supervision. CMD: conceptualization, methodology, supervision. All authors: writing - review \& editing.

Acknowledgements: Chiara Rohardt, Maximilian Gertler, Elisabeth Linzbach, Domenika Pettenkofer, Christian Schönfeld, Julian Bernhard.

Conflict of interest: None declared.

Support statement: C.M. Denkinger reports grants from Foundation for Innovative New Diagnostics (FIND), and Ministry of Science, Research and Culture, State of Baden Wuerttemberg, Germany, to conduct of the study. This work was funded as part of FIND's work as co-convener of the diagnostics pillar of the Access to COVID-19 Tools (ACT) Accelerator, including support from Unitaid [grant number: 2019-32-FIND MDR], the government of the Netherlands [grant number: MINBUZA2020.961444], from the UK Foreign, Commonwealth and Development Office [FCDO, formerly DFID, grant number 300341-102], and the World Health Organization. T.C. Jones is in part funded through NIAID-NIH CEIRS contract HHSN272201400008C. FIND supplied the test kits for the study. The study was support by Heidelberg University Hospital and Charité University Hospital internal funds.

Data availability: All raw data and analysis code are available upon a request to the corresponding author.

Ethics: This study was approved by the ethics committee of Charité - Universitätsmedizin (EA1/371/20) and of the Heidelberg University Hospital (Registration number S-180/2020). 
medRxiv preprint doi: https://doi.org/10.1101/2021.06.15.21258502; this version posted June 15, 2021. The copyright holder for this preprint (which was not certified by peer review) is the author/funder, who has granted medRxiv a license to display the preprint in perpetuity.

It is made available under a CC-BY-NC-ND 4.0 International license .

\section{References}

1. European Centre for Disease Prevention and Control. Threat Assessment Brief: Rapid increase of a SARS-CoV-2 variant with multiple spike protein mutations observed in the United Kingdom, December 2020. https://www.ecdc.europa.eu/en/publications-data/threatassessment-brief-rapid-increase-sars-cov-2-variant-united-kingdom. Accessed 4 May 2021.

2. World Health Organization. Weekly epidemiological update on COVID-19-1 June 2021. https://www.who.int/publications/m/item/weekly-epidemiological-update-on-covid-19---1june-2021. Accessed 7 June 2021.

3. Centers For Disease Control and Prevention. COVID-19 data tracker weekly review. https://www.cdc.gov/coronavirus/2019-ncov/covid-data/covidview/index.html. Accessed 4 May 2021.

4. Robert Koch Institute. Bericht zu Virusvarianten von SARS-CoV-2 in Deutschland (28.4.2021). https://www.rki.de/DE/Content/InfAZ/N/Neuartiges_Coronavirus/DESH/Bericht_VOC_202104-28. Accessed 4 May 2021.

5. Public Health England. 12 February 2021. Guidance SARS-CoV-2 lateral flow antigen tests: evaluation of VOC1 (Kent, UK) and VOC2 (South Africa). https://www.gov.uk/government/publications/sars-cov-2-lateral-flow-antigen-testsevaluation-of-voc1-and-voc2/sars-cov-2-lateral-flow-antigen-tests-evaluation-of-voc1-kentuk-and-voc2-south-africa. Accessed 21 May 2021.

6. Foundation for Innovative New Diagnostics. SARS-CoV-2 variants. March 2021. https://www.finddx.org/wp-content/uploads/2021/03/COVID-variants-report-FINAL12MAR2021.pdf. Accessed 5 May 2021.

7. PATH. Implication of variants on COVID-19 antigen test detection. https://www.path.org/programs/diagnostics/covid-dashboard-implication-variants-covid-19antigen-test-detection/. Accessed 11 June 2021.

8. Public Health England. 23 December 2020. SARS-CoV-2 lateral flow antigen tests: evaluation of VUI-202012/01. https://www.gov.uk/government/publications/sars-cov-2-lateral-flowantigen-tests-evaluation-of-vui-20201201/sars-cov-2-lateral-flow-antigen-tests-evaluationof-vui-20201201. Accessed 4 May 2021.

9. Foundation for Innovative New Diagnostics. SARS-CoV-2 diagnostic pipeline. https://www.finddx.org/covid-19/pipeline/?section=immunoassays\#diag_tab. Accessed 18 May 2021.

10. Krüger L, Gaeddert M, Köppel L, Brümmer LE, Gottschalk C, Miranda IB, Schnitzler P, Kräusslich HG, Lindner AK, Nikolai O, Mockenhaupt FP, Seybold J, Corman VM, Drosten C, 
medRxiv preprint doi: https://doi.org/10.1101/2021.06.15.21258502; this version posted June 15, 2021. The copyright holder for this preprint (which was not certified by peer review) is the author/funder, who has granted medRxiv a license to display the preprint in perpetuity.

It is made available under a CC-BY-NC-ND 4.0 International license .

Pollock NR, Cubas-Atienzar Al, Kontogianni K, Collins A, Wright AH, Knorr B, Welker A, de Vos $M$, Sacks JA, Adams ER, Denkinger CM. 2020. Evaluation of the accuracy, ease of use and limit of detection of novel, rapid, antigen-detecting point-of-care diagnostics for SARS-CoV-2.

medRxiv doi:10.1101/2020.10.01.20203836:2020.10.01.20203836.

11. van Loon W, Rössig H, Burock S, Hofmann J, Bernhardt J, Linzbach E, Pettenkofer D, Schönfeld C, Gertler M, Seybold J, Kurth T, Mockenhaupt FP. 2021. Emergence of the SARS-

CoV-2 B.1.1.7 lineage and its characteristics at an outpatient testing site in Berlin, Germany, January-March 2021. medRxiv doi:10.1101/2021.04.15.21255389:2021.04.15.21255389.

12. Jungnick S, Hobmaier B, Mautner L, Hoyos M, Haase M, Baiker A, Lahne H, Eberle U, Wimmer C, Hepner S, Sprenger A, Berger C, Dangel A, Wildner M, Liebl B, Ackermann N, Sing A, Fingerle V, Bavarian S-C-PHLT, Bavarian S-C-PHLT. 2021. Detection of the new SARS-CoV-2 variants of concern B.1.1.7 and B.1.351 in five SARS-CoV-2 rapid antigen tests (RATs), Germany, March 2021. Euro Surveill 26.

13. Bekliz M, Adea K, Essaidi-Laziosi M, Sacks JA, Escadafal C, Kaiser L, Eckerle I. 2021. Analytical comparison of nine SARS-CoV-2 antigen-detecting rapid diagnostic tests for emerging SARSCoV-2 variants. medRxiv doi:10.1101/2021.05.31.21258111:2021.05.31.21258111.

14. US Food and Drug Administration (FDA). Policy for Evaluating Impact of Viral Mutations on COVID-19 Tests. https://www.fda.gov/regulatory-information/search-fda-guidancedocuments/policy-evaluating-impact-viral-mutations-covid-19-tests. Accessed 18 May 2021. 